DOI: $10.19195 / 0137-1134.104 .12$

JAROSŁAW MIKOŁAJEWICZ

\title{
SYSTEM PRAWA W PERSPEKTYWIE JEGO STOSOWANIA
}

Profesorowi Stanisławowi Kaźmierczykowi $w$ osiemdziesięciolecie urodzin $w$ darze

Niniejsze opracowanie poświęcono zagadnieniu systemu prawnego w stosowaniu prawa. Ze względu na narzucone, skromne, rozmiary tekstu zostaną w nim poruszone jedynie wybrane zagadnienia, bezpośrednio związane z przedmiotową problematyką. W szczególności kwestie własności systemu warunkujących jego operatywność, od poznawania elementów systemu prawnego traktowanego jako zbiór w sensie dystrybutywnym, a to w kontekście orzekania o wyznaczaniu podmiotom prawa określonych sytuacji prawnych.

Takie ujęcie, nawet jeśli niekoniecznie ukierunkowane na bezpośrednie zastosowania prawnicze w konkretnych postępowaniach, zakłada perspektywę socjologiczną. Dopiero wtórnie zaś antropologiczno-filozoficzną i kognitywną. To o tyle istotne, o ile trafne jest spostrzeżenie, iż postęp wszelkiej wiedzy wiąże się nierozerwalnie $\mathrm{z}$ doskonaleniem metody badania. Od przełomu w metodzie wziął początek współczesny sposób patrzenia na naukowość, a stąd i współczesny obraz świata ${ }^{1}$. Zda się, że ewoluować powinny i metody prawoznawstwa. Nie wdając się w bliższe wyjaśnienia, autor uważa, że w interesującym obecnie zakresie stricte jurydyczny opis jest już dalece niewystarczający, zbyt dalekie oderwanie się od niego może jednak spowodować prawniczą nieoperatywność, to zaś grozi utratą prawoznawczych wartości nauki prawa. Stąd - nieco ex cathedra - uważa

1 W. Wundt, Beiträge zur Theorie der Sinneswahrnehmung, Leipzig und Heidelberg 1862, s. IV-XI, https://archive.org/details/beitrgezurtheor00wundgoog (dostęp: 8.02.2016). 
on obecnie za prawomocny derywacyjno-walidacyjny model decyzyjny prawa L. Leszczyńskiego. Przyjmowana przezeń perspektywa wydaje się najbardziej dogodna do dokonywania analizy sytuacji, gdzie proste odwołanie do jakoś dających się charakteryzować pod względem formalnym elementów systemu prawnego dyskusję może co najwyżej wstępnie porządkować.

Tak przedmiotowo ujmowany system prawny jest, po pierwsze, jednym z wielu (sub)systemów społecznych; po wtóre, systemem, który jako operacyjnie zamknięty, pozostaje otwarty na informacje płynące z innych (sub)systemów społecznych: moralności, religii, gospodarki, polityki itd. Te własności ${ }^{2}$ decydują o swoistości prawa, które aczkolwiek w prawniczym ujęciu da się zapewne sprowadzić i sprowadza się do jakoś pojętego systemu norm to przecież nie jest dane w bezpośrednim poznaniu owych norm, a istotnie poprzez akty normatywne, jurydyczne dyskursy, konwencje, literaturę prawniczą (w tym formułowane koncepcje naukowe) etc. Socjologiczne ujmowanie systemu społecznego ${ }^{3}$, istotnie nie przedstawia się jako szczególnie użyteczne z punktu widzenia prawnika. Szczególnie jeśli przez ową użyteczność rozumie się nie badanie istoty prawa, jego systemowej natury, a ustalanie jego pojmowania przez prawników, które rzutuje na ich procesy decyzyjne czy identyfikację problemów formułowanych wprost przez praktykę prawniczą.

System prawny może być pojmowany na dwa zasadniczo różne sposoby: (1) wszystkie normy prawne, które według jakichś kategorii przynależności systemowej go tworzą (zbiór w sensie dystrybutywnym), (2) pewną całość złożoną z owych norm (zbiór kolektywny). Pierwszy przypadek użycia ma odzwierciedlenie w zdaniach typu „,normy prawa polskiego stanowią...”, drugi w: ,polskie prawo cywilne dzieli się na prawo rzeczowe, spadkowe, zobowiązań, rodzinne, handlowe itd."4 Prawnicy przyjmują przy tym, że system prawa jest wewnętrznie uporządko-

2 Rozpoznane w pracach N. Luhmana, Soziale Systeme. Grundriss einer allgemeinen Theorie, Frankfurt a.M. 1984; idem, Die Wirtschaft der Gesellschaft, Frankfurt a.M. 1988; idem, Das Recht der Gesellschaft, Frankfurt a.M. 1993; idem, Die Gesellschaft der Gesellschaft, Frankfurt a.M. 1997; por. opracowanie T. Hubera: Systemtheorie des Rechts. Die Rechtstheorie Niklas Luhmanns, Baden-Baden 2007; za swoiście praktyczne ujęcie tego mogłoby uchodzić G. Teubnera, Recht als autopoietisches System, Suhrcamp, Frankfurt a.M. 1989, którą nawet otwiera odwołanie do tekstu religijnego — talmudycznej hagady „Und Gott lachte...” [I Bóg się roześmiał — J.M.], jakby wbrew polskiej tradycji rozprawiania o koncepcji Teubnera — jakoby zamkniętej w owych przedstawieniach.

3 Współcześnie kształtowane w kręgu Society for General Systems Research (obecnie International Society for the Systems Sciences) mające swoje praźródła w pracach B. Malinowskiego, którego śmiało nazwać można ojcem — przynajmniej brytyjskiego, a pośrednio i amerykańskiego — funkcjonalizmu, ale przecież również socjologicznej koncepcji instytucji H. Schelsky'ego.

4 Oczywiście kategorią nadrzędną jest ,system prawa polskiego”, którego część stanowi „polskie prawo cywilne". 
wany, ze względu na relacje zachodzące między tworzącymi go elementami. Przyjmuje się, że pomiędzy elementami systemu prawa zachodzą odpowiednie związki na płaszczyźnie poziomej (podział na gałęzie prawa) i pionowej (zależności hierarchiczne), a także, że zbiór ten musi spełniać warunki spójności i zupełności ${ }^{5}$. Taka charakterystyka systemu prawa jako zjawiska ujmowanego w różnych swoich aspektach jako odmienne kategorialnie zbiory pociąga za sobą nie tylko określoną wizję przedmiotu - prawa, ale nawet pewne dopuszczalne (na sposób D. Scotiusa możliwe) jego ujęcia. W określonym sensie wyznacza uniwersum badawcze prawoznawstwa. Podział prof. S. Kaźmierczyka na płaszczyźnie poziomej warunkuje sensowność pytań nie tylko o samą „gałęziową naturę prawa”, ale sensowność zagadnień o bezpośredniej doniosłości dla stosowania prawa w ramach — już uznanych - gałęzi.

Podział na gałęzie uzasadnia stawianie pytań o ich specyfikę wykładniczą (dopuszczalność określonych metod wykładni na gruncie danej gałęzi, w szczególności analogiczności czy odpowiedniości stosowania określonych regulacji; spójności ${ }^{6}$ — jedności czy autonomii pojęciowej, w szczególności problem tzw. zasięgu definicji legalnych, ale i doktrynalnych; swoistości aparatury teoretycznej; zakresu stosowania tzw. precedensów czy prawa sędziowskiego ${ }^{7}$; krótko problemat tzw. dyscyplin wykładniczych), ale i funkcje, cele, charakterystykę oraz genezę. Problemy te mają podstawową doniosłość, również praktyczną ${ }^{8}$. Natomiast nie od rzeczy jest zauważyć, że istotnie tradycyjne kryteria wyróżniania gałęzi prawa muszą ustępować kryterium funkcjonalnemu. Przy założeniu sensowności tego typu operacji, na przykład dla potrzeb wyróżniania prawniczych dyscyplin egzegetycznych poprzez podział zadań w zakresie wykładni i systematyzacyjnych wydaje się, że tego typu metoda przedstawia się jako uzasadniona. Problem polegający na tym, że poszczególne akty normatywne mogą się przy tym okazywać przyporządkowane więcej niż jednoznacznie, nie przedstawia się przy tym nie tylko jako nadmierny koszt, ale wprost jako efekt właściwie rozeznanych własności

5 Szerzej S. Kaźmierczyk, Kryteria autonomii gałęzi prawa, [w:] Z Zagadnień teorii i filozofii prawa. Autonomia prawa, red. W. Gromski, Wrocław 2001, s. 117-133.

${ }^{6}$ Ostatnio w literaturze polskiej na ten temat: Z. Pulka, Założenia spójności semantycznej systemu prawa w klaryfikacyjnej teorii wykładni, „Przegląd Prawa i Administracji” 102, Postanalityczna filozofia prawa, 2015.

7 Wprawdzie oficjalnie nasza kultura prawna opowiada się po stronie dość radykalnie pojmowanej zasady „Legibus, non exemplis iudicandum” (Sądzić należy według ustaw, a nie według precedensów), wyniki realnych badań wskazują jednak, że rola precedensów i to w złożonym rozumieniu (nie jako wyprowadzonego z orzeczenia ratio decidendi) jako pewnych wzorów rozumowań bynajmniej nie jest mała (M. Koszowski, Anglosaska doktryna precedensu. Porównanie z polska praktyka orzecznicza, Warszawa 2009, szczególnie s. 62-76). Przykładowe studium przypadku patrz: J. Mikołajewicz, Glosa do wyroku Wojewódzkiego Sądu Administracyjnego w Poznaniu z 27.11.2008 r. IV SA/Po 210/08,OSP 2009 nr 11 poz. $116 a$.

${ }^{8}$ Ostatnio zostały interesująco postawione przez G. Grzegorczyka, w niepublikowanej pracy doktorskiej napisanej pod kierunkiem A. Batora, pt. Kompleksowe regulacje prawne i ich miejsce w porzadku prawnym, Wrocław 2015. 
tekstu prawnego, którego jednostki podstawowe (nie tylko w szkole poznańskiej zwane przepisami prawnymi) wysłowiają normy pluralnie.

Najczęściej prawnicy traktują o prawie, mając na myśli inny zbiór (raczej zbiory, bo ich elementy są różne) — w sensie dystrybutywnym ${ }^{9}$.

Funkcjonującym prawem jest zbiór obowiązujących norm postępowania. Natomiast w praktyce rozważań prawniczych pojawiają się i inne ujęcia prawa, w niektórych zresztą przypadkach nader użyteczne jako swoistego rodzaju skróty myślowe ułatwiające operacjonalizację nader złożonych ze swojej natury rozważań.

Podstawowym problemem dotyczącym sposobu pojmowania systemu prawa, który skądinąd zawsze wystąpi w przypadku rozpatrywania jakichś zbiorów dystrybutywnych, jest rozstrzygnięcie, jakie elementy należą do analizowanego zbioru. To, jakie elementy zakwalifikuje się do określonego zbioru bynajmniej nie przesądza jednak o treści pojęcia „zbiór”. Trzeba podnieść i to, że pojęcie owo, w jedynym — zdaniem autora - rzeczywiście użytecznym jego znaczeniu, nie jest w ogóle nazwą, a jeśli tak je traktować, to jako nazwę na elementy klasy: „zbioru zbiorów”. Z tego powodu oraz faktu posługiwania się pojęciami prawa na określenie nader różnych zbiorów, wynika konieczność postawienia jasno zagadnienia, jakie argumenty są przyłączane do tego funktora. Stąd wskazanie, w jaki sposób jest pojmowany system prawa właśnie jako zbiór, poprzez charakterystykę jego elementów, oraz wskazanie, jakie relacje zachodzą pomiędzy różnymi zbiorami określanymi mianem systemu prawnego. Takie semiotyczne podejście do problemu ma tę podstawową zaletę, że nie wymaga niejako przednawiasowego rozstrzygnięcia wielu problemów filozoficznych, czy wprost zwalnia z obowiązku ich sformułowania ${ }^{10}$. Jest to szczególnie dogodne w przypadku rozważań tego typu jak niniejsze, gdy całkiem zasadnie można — i to właśnie wstępnie — założyć, że akurat co do zagadnień filozoficznych brakuje zgody wśród podmiotów prawniczego dyskursu.

\section{IV}

W tym miejscu należy stwierdzić, że najczęściej elementami różnie pojętych zbiorów oznaczanych mianem ,systemu prawnego” bywają określane: akty normatywne, przepisy prawne oraz normy prawne ${ }^{11}$. Co do dwóch pierwszych, da

9 Na temat pojmowania ,zbiorów” patrz Z. Ziembiński, Logika praktyczna, Warszawa 1992, s. 28, co do zbioru w sensie kolektywnym, szerzej T. Kotarbiński, Wykłady z dziejów logiki, Łódź 1957, s. 121, s. 180 n., idem, Elementy teorii poznania, logiki formalnej i metodologii nauk, Warszawa 1986, s. 25 n.

10 J. Pelc, Wstep do semiotyki, Warszawa 1984, s. 35.

11 Szersze omówienie, patrz: J. Mikołajewicz, Pojmowanie prawa, [w:] Problematyka intertemporalna w prawie. Zagadnienia podstawowe. Rozstrzygnięcia intertemporalne. Geneza, funkcje, aksjologia, red. J. Mikołajewicz, Warszawa 2015, s. 79 n. 
się zastosować, omawiana przez S. Kaźmierczyka, więź pionowa - powiązania hierarchiczne, których stwierdzenie przesądza o samej możliwości przynależenia do w określony sposób rozumianego systemu prawnego. Kwestią niezmiernie złożoną jest natomiast hierarchiczna charakterystyka norm danego systemu, o ile w ogóle można mówić o takiej hierarchii. Relacją aktualizującą przynależność, i to we wszystkich wskazanych zbiorach, jest — nader różnie pojmowane ${ }^{12}$ obowiązywanie.

Funktor „obowiązuje”, wiąże różne argumenty. Elementem wspólnym wszystkich tak powstałych wyrażeń jest fakt wyznaczania, zgodnie z treścią wyrażenia - argumentu, obowiązku posłuchu. Prawnicy posługują się jednak pojęciem obowiązywania w zasadniczo odmienny sposób. Mianowicie w odniesieniu do postępowania konkretnego podmiotu w konkretnych okolicznościach, któremu dana norma wyznacza określone postąpienie (np. Sędziego obowiązuje noszenie togi podczas rozprawy). W tego typu zwrotach termin „obowiązuje” wyznacza relację między podmiotem - adresatem danej normy, a tą normą (krótko: określa zakres adresatów danej normy czy elementy tego zbioru), zwykle względem elementów jej zakresu zastosowania i normowania ${ }^{13}$. Należy jednak odróżniać obowiązywanie normy prawnej (czy — jak wyżej wskazano - innego obiektu), które jest stanem niepodzielnym, od aktualnego czy potencjalnego wyznaczania określonym podmiotom określonego postąpienia przez owe obiekty ${ }^{14}$. Kategorialną różnicę między tak pojętymi „obowiązywaniami” stosunkowo łatwo zresztą uchwycić. Trzymając się niniejszego przykładu, o tyle sędziego obowiązuje noszenie togi podczas rozprawy, o ile obowiązuje norma nakazująca mu takie postępowanie. W poniższych rozważaniach będzie mowa o obowiązywaniu w pierwszym znaczeniu. W drugim, gdy poruszone zostanie zagadnienie sytuacji prawnych.

Dla zachowania jasności pojęciowej wypada jednak podkreślić, że nie każda relatywizacja zwrotu „obowiązuje”, poza odniesieniem do samej nazwy obiektu obowiązującego, konstytuuje inne rodzajowo znaczenie tego terminu.

Zasadniczo odmienną od relatywizacji obowiązywania w odniesieniu do podmiotu obowiązanego kwestią jest bowiem temporalny charakter obowiązywania. Obowiązywanie, jako takie, określonego obiektu traktuje się jako pewnego rodzaju fakt społeczny, stąd trwa w czasie. Także u Hansa Kelsena normy podstawowe

12 Szeroko o obowiązywaniu: A. Grabowski, Prawnicze pojęcie obowiazywania prawa stanowionego. Krytyka niepozytywistycznej koncepcji prawa, Kraków 2009. Książka spotkała się z dość niezwykłą, co do formy, ale i merytorycznie niefortunną recenzją T. Pietrzykowskiego, $W$ poszukiwaniu Świętego Graala: Andrzej Grabowski o prawniczym pojęciu obowiąywania prawa, „Archiwum Filozofii Prawa i Filozofii Społecznej” 2010, nr 1, s. 64-77.

13 Zatem i charakterystyka syntaktyczna tego zwrotu jest odmienna. Nie jest to wszak funktor jednoargumentowy.

14 Z. Ziembiński, O stanowieniu i obowiazywaniu prawa. Zagadnienia podstawowe, Warszawa 1995, s. 17-18. 
uzasadniające poszczególne systemy prawne są zmienne w czasie ${ }^{15}$. Warto również zauważyć, że normy zasadnicze traktowane w opisach radykalnych koncepcji jusnaturalistycznych jako wiążące zawsze i wszędzie, obowiązują w skończonym przecież świecie. W tym sensie można mówić jedynie o czasowym charakterze obiektu obowiązującego, ale przecież nie o innym pojęciu obowiązywania.

System prawny najczęściej nie interesuje prawnika praktyka sam przez się i dla siebie. Takie ambicje poznawcze miewają teoretycy - uczeni prawa. Działania prawnika praktyka są nastawione na poszukiwanie odpowiedzi praktycznej: jaka sytuacja prawna jest wyznaczona określonemu podmiotowi. Co sprowadza się do relatywizacji treści normy $\mathrm{N}$ jako wyznaczającej na moment t określonemu podmiotowi $\mathrm{P}$ (w warunkach polskich, jako podmiotowi rodzaju $\mathrm{R}$, założenie generalności norm prawnych!) obowiązku albo właśnie niewyznaczaniu żadnego obowiązku prawnego (indyferencja prawna). Stąd znaczenie problematyki nie tylko obowiązywania, ale i spójności oraz zupełności prawa, które to wszystkie relacje traktuje się jako relacje systemowe konstytuujące system prawa pojmowany jako system norm prawnych. Bez przyjęcia założenia o systemowości prawa ustalenie sytuacji prawnej danego podmiotu przedstawia się jako co najmniej trudniejsze.

Nie ma możliwości poczynienia szerszych uwag ${ }^{16}$ o sytuacjach prawnych w niniejszym opracowaniu. Pewna wzmianka porządkowa wydaje się jednak konieczna.

Konstrukcja „sytuacji prawnej” jest dorobkiem europejskiej kultury prawnej. Pierwszy użył jej bodaj, we współczesnym sensie, L. Duguit, co znalazło wyraz pod pojęciami „sytuacji prawnej indywidualnej” oraz „sytuacji prawnej ustawowej"17. Również polska kultura prawna przyswoiła sobie kategorię sytuacji prawnych $^{18}$.

15 Aczkolwiek gwoli rzetelności wypada przypomnieć, że według autora same, jako ,transcendentalno-logiczne założenie" nie obowiązują. H. Kelsen, Pure Theory of Law, Gloucaster 1989. s. 201-205.

16 Szerzej na ten temat w: Problematyka intertemporalna w prawie. Zagadnienia podstawowe. Rozstrzygnięcia intertemporalne. Geneza, funkcje, aksjologia, red. J. Mikołajewicz, Warszawa 2015, s. $160 \mathrm{n}$.

17 L. Duguit, Traite ‘de droit constitututionnel, t. II, Paris 1923, s. 202 n.

18 Jako podstawę rozważań przyjmuje się aparaturę wypracowaną przez Z. Ziembińskiego: Problemy podstawowe prawoznawstwa, Warszawa 1980, s. 349 n.; idem, O aparaturze pojęciowej dotyczacej sytuacji prawnych, „Państwo i Prawo” 3, 1985; idem, O zawitościach związanych z pojęciem kompetencji, „Państwo i Prawo”4, 1992. Ujęcie podręcznikowe w: Z. Ziembiński, Teoria prawa, wyd. I, Warszawa $1972 \mathrm{n}$. Koncepcja ta powstawała stopniowo, pierwszym opracowaniem tego autora w tej mierze było, zdaje się to pt.: Próba uporządkowania podstawowego słownictwa 
Używa się jej na dwa sposoby, zawsze jednak jako funktora wiążącego jakąś nazwę indywidualną albo generalną. W pierwszym przypadku mowa o sytuacji prawnej określonego podmiotu, w drugim — o sytuacji określonej kategorii podmiotów. Wyróżnia się sytuacje prawne podstawowe i pochodne:

1) podstawowa sytuacja prawna jest wyznaczana adresatowi normy prawnej bezpośrednio normą prawną (częściej jakimś spójnym zespołem norm prawnych) bez odnoszenia do zachowań innych podmiotów;

2) pochodne sytuacje prawne powstają, gdy mamy do czynienia z modalnością pochodną, to jest kwalifikacją zachowań jako odnoszących się do jakieś osoby ze względu na inną osobę niż adresat normy.

Sytuacje prawne mogą być złożone, gdy w ich obrębie da się wyodrębnić więcej niż jedną sytuację prawną (w najprostszym przypadku może to być jakaś sytuacja prosta połączona $\mathrm{z}$ sytuacją złożoną), albo proste, gdy w ich obrębie nie da się wyodrębnić przynajmniej dwóch sytuacji.

Z punktu widzenia konstrukcyjnego stosunek prawny czy prawo podmiotowe ujmuje się jako złożone sytuacje prawne. Zwykle jednak nakłada się na owe konstrukcje jakieś warunki faktyczne, co statuuje te kategorie jako posiadające poza aspektami stricte jurydycznymi — i aspekt socjologiczny.

\section{VI}

Dla zarysowania sytuacji prawnej określonego podmiotu konieczne jest zatem odniesienie do obowiązującej w relewantnym momencie normy prawnej. Jak jednak wiadomo, normy prawne nie są formułowane przez prawodawcę faktycznego wprost, co do zasady kodowane są w przepisy prawne zawarte w aktach normatywnych. M. Zieliński — twórca oryginalnej, polskiej koncepcji wykładni ${ }^{19}$, bez przesady pisze zatem:

W problematyce wykładni ześrodkowują się [...] nieomal wszystkie problemy nauki i praktyki prawniczej. Wszystko, co się w nauce i praktyce prawniczej czyni, albo wprost polega na wykładni, albo jej dotyczy, albo wykładnię rozwija, albo wykładnię przejawia, albo wykładnię uwzględnia, albo ją po prostu warunkuje ${ }^{20}$.

prawniczego, „Studia Logica” XV, 1964; opracowaniem już pełniejszym: Logiczne podstawy prawoznawstwa. Wybrane zagadnienia, Warszawa 1966, s. 89-118 (rozdzial IV, „Modalności normatywne”, w szczególności § 4: „Modalności normatywne złożone”, s. 106-114).

19 Polska kultura prawna wniosła wiele do myśli wykładniczej. Ostatnio S. Tkacz przypomniał niemal całkowicie zapoznanego w tej mierze L. Petrażyckiego (S. Tkacz, O wykładni prawa w teorii Leona Petrażyckiego, [w:] O prawie i jego dziejach księgi dwie. Studia ofiarowane Profesorowi Adamowi Lityńskiemu w czterdziestolecie pracy naukowej i siedemdziesięciolecie urodzin, red. M. Mikołajczyk et al., księga II, Białystok 2010, s. 383-398.

20 M. Zieliński, Wykładnia prawa. Zasady, rady, wskazówki, Warszawa 2002, s. 14. 
Problem tkwi w tym, że normy prawne nie tylko nie występują w „stanie wolnym", ale ich zbiór również ulega przekształceniom, przestają obowiązywać, $\mathrm{w}$ określonym sensie ${ }^{21}$ podlegają zmianom ${ }^{22}$. Odtworzone ${ }^{23} \mathrm{w}$ złożonych czynnościach intelektualnych normy prawne pozostają do siebie w relacjach spójności (zgodności) oraz zupełności. Skądinąd wydaje się, że przy okazji, po raz kolejny, ukazuje się symplicyzm ujmowania prawa jako zbioru bezpośrednich wytworów działalności prawotwórczej. W żaden bowiem sposób poprawnie o tych własnościach systemu nie można dyskutować na poziomie aktów normatywnych, a nawet przepisów prawnych.

Nie ma w tym miejscu możliwości argumentować za przyjęciem określonej koncepcji wykładni jako wykazującej, w określonym sensie, przewagę nad innymi przyjmowanymi w kręgu naszej kultury prawnej24. Trzeba zatem w tym miejscu stwierdzić, że adekwatna jest rozwinięta koncepcja wykładni M. Zielińskiego.

Jak słusznie wskazywał S. Kaźmierczyk, jedną z własności systemu prawa jest jego zupełność. Choć prawo traktuje się jako realnie funkcjonujący system aksjonormatywny, własności tej nie rozumie się jednak w kategoriach empirycz-

21 Ściśle rzecz biorąc, przyjęcie definicji normy postępowania będącej analogonem definicji zdania w sensie logicznym, norma zmieniona nie jest tą samą normą, co przed zmianą. W tym sensie zawsze mamy do czynienia ze zmianą norm w systemie.

$22 \mathrm{Na}$ temat zmian w prawie ujmowanym w ten sposób jak w niniejszym opracowaniu, szeroko, J. Mikołajewicz, Zmiana prawa, [w:] Problematyka intertemporalna w prawie. Zagadnienia podstawowe. Rozstrzygnięcia intertemporalne. Geneza, funkcje, aksjologia, red. J. Mikołajewicz, Warszawa 2015, s. 111-150.

23 Koncepcja wykładni prawa M. Zielińskiego (zwana derywacyjną), przyjęta w tym opracowaniu, zakłada, że prawo pojmowane jako system norm prawnych w pewien sposób istnieje przed aktem wykładni. Dotychczas nikt nie zajął się problematyką wartości prawnych, które legły u podstaw tej koncepcji, w tej mierze zapewne chodziłoby jednak przede wszystkim o zasady: suwerenności narodu, rozdziału władz, państwa prawnego (praworządności) oraz demokracji.

24 Tego typu argumentację, a nawet pewne możliwości rozwojowe i adaptacyjne koncepcji wykładni M. Zielińskiego, zostały przedstawione w: J. Mikołajewicz, O możliwych rozwinięciach Macieja Zielińskiego koncepcji wyktadni prawa, [w:] W poszukiwaniu dobra wspólnego. Księga jubileuszowa Profesora Macieja Zielińskiego, red. A. Choduń, S. Czepita, Szczecin 2010. Intuicje te znalazły potwierdzenie. Koncepcja Zielińskiego odpowiada na multicentryczność prawa (A. Bator, $O$ adekwatności założeń derywacyjnej koncepcji wyktadni do badań nad interpretacja prawa Unii Europejskiej, „Studia Prawa Prywatnego” 2, 2015; A. Godek, Zagadnienia wyktadni prawa $w$ unijnych kontekstach interpretacyjnych. O adekwatności i możliwych rozwinięciach derywacyjnej koncepcji wykładni, niepublikowana praca doktorska pod kierunkiem J. Mikołajewicza, Poznań 2014; idem, Zastosowanie derywacyjnej koncepcji wykładni prawa do rozstrzygania spraw ze stosowaniem przepisów unijnych, „Ruch Prawniczy, Ekonomiczny i Socjologiczny” 1, 2011; idem, On legal situations and interpretation of Union law, „Studia Prawa Prywatnego” 2, 2015, jego temporalną wielowarstwowość (Problematyka intertemporalna w prawie. Zagadnienia podstawowe. Rozstrzygnięcia intertemporalne. Geneza, funkcje, aksjologia, red. J. Mikołajewicz, Warszawa 2015), doskonale wpisuje się w europejską tradycję filozofii analitycznej (T. Barankiewicz, O pożytkach interpretacyjnych brytyjskiej filozofii analitycznej, „Studia Prawa Prywatnego” 2, 2015 SPP), a także nadaje się do bezpośredniego wykorzystania nie tylko na gruncie prawa publicznego (A. Pyrzyńska, Kilka uwag o wyktadni prawa cywilnego, „Studia Prawa Prywatnego” 2, 2015). 
nych. Owszem, faktycznie pojmowana zupełność prawa jest częstą w praktyce przyczyną sporów. Najczęściej chodzi jednak o spór aksjologiczny albo wykładniczy, szczególnie w przypadku rozważań o dopuszczalności zastosowania wykładni nie znajdującej bezpośredniego oparcia w konkretnym przepisie prawnym. Zupełność prawa jest zatem własnością — założeniem konstytuującym prawo jako system, nie zaś hipostatyczną własnością systemu (jak nie ma idealnej prostej, którą da się przeprowadzić w danym nam świecie, tak trudno sobie przedstawić na tyle doskonały wytwór kultury — prawo, w którym nie występowałyby jakieś luki konstrukcyjne). Wyjaśnieniem swoistego paradoksu zupełności prawa może być ustanowienie normy kompetencji normodawczej w warunkach stanowienia łącznego ${ }^{25}$. W ten sposób, zachowując tezę o ekskluzywności prawa, można wyjaśnić nie tylko przypadki wykładni naprawczej, ale współkształtującej prawo.

O zupełności systemu prawnego mówi się w kilku znaczeniach. Dla praktyki prawniczej szczególne znaczenie ma zupełność traktowana jako zupełność podstaw prawnych decyzji stosowania prawa - w dwóch aspektach:

1) zupełności kwalifikacyjnej — na gruncie każdego systemu prawnego da się sformułować podstawne zdanie, że każde dowolne zachowanie jakiegokolwiek podmiotu prawnego można kwalifikować w kategoriach obowiązku prawnego (indyferencja prawna jest definiowalna poprzez odniesienie do pojęcia obowiązku prawnego!);

2) zupełności decyzyjnej, na gruncie każdego systemu prawnego da się wylegitymować jakąkolwiek decyzję stosowania prawa w jego własnych kategoriach. $\mathrm{Z}$ punktu widzenia praktycznego rzecz można by sprowadzić do tezy, że na gruncie prawa jakiekolwiek zagadnienie prawne zawsze jest rozstrzygalne.

Zupełność decyzyjną uzyskuje się przy tym niejednokrotnie w drodze złożonych rozumowań prawnych. Na szczególną uwagę w tej mierze zasługują rozumowania oparte na tak zwanych zasadach prawa. Jak wskazują L. Leszczyński oraz G. Maroń, należy wyróżnić trzy aspekty zasadniczości zasad prawa: pozycja hierarchiczna, „zasadniczość” — „doniosłość” przedmiotu ochrony, wreszcie — podstawa rozumowań prawniczych ${ }^{26}$. Ten trzeci przypadek jest szczególnie istotny z punktu odtwarzania elementów systemu nieodpoznawanych w drodze interpretacji bezpośrednich wytworów czynności prawotwórczych. Autor niniejszego opracowania sądzi, że właśnie ten trzeci aspekt prowadzi do tak głębokiego zainteresowania zasadami prawa ${ }^{27}$. Wylegitymizowanie określonej koncepcji zasad

25 C. Znamierowski, Prolegomena do nauki o państwie, Poznań 1947, s. 145 n.

${ }^{26}$ L. Leszczyński, G. Maroń, Pojęcie i treść zasad prawa oraz generalnych klauzul odsyłajacych. Uwagi porównawcze, „Annales Universitatis Mariae Curie-Skłodowska. Sectio G, Ius.” 60, 2013, z. 1, s. 81-82.

$27 \mathrm{Na}$ temat kryteriów wyróżniania zasad prawa w polskiej teorii prawa patrz (w klasycznym już ujęciu podręcznikowym): J. Wróblewski, [w:] Teoria państwa i prawa, red. W. Lang, J. Wróblewski, S. Zawadzki, Warszawa 1979, s. 359 n.; z wprowadzeniem rozróżnienia zasad opisowych 
prowadzi do wylegitymizowania systemu prawnego, przynajmniej w określonym zakresie, o określonych treściach normatywnych ${ }^{28}$.

Drugą istotną cechą formalną każdego systemu prawnego pojmowanego w najbardziej użytecznym ujęciu: jako system norm prawnych, jest spójność. Kiedy mówi się, że system prawny jest spójny, twierdzi się tym samym, że nie występują normy formalnie ze sobą niezgodne ${ }^{29}$, które byłyby zaliczane do owego systemu ${ }^{30}$. System, który rzeczywiście zawierałby w sobie takie normy, jako nienadający się do kierowania ludzkimi zachowaniami, nie byłby systemem prawnym. Podstawową bowiem zasadą przyjmowaną, co do obowiązywania prawa jest zasada impossibilium nulla obligatio est ${ }^{31}$, zaś podstawowym założeniem przyjmowanym przy badaniach nad systemem prawnym jest założenie

i dyrektywalnych S. Wronkowska, M. Zieliński, Z. Ziembiński, Zasady prawa. Zagadnienia podstawowe, Warszawa 1974, zwłaszcza s. 5 n. Z literatury najnowszej: M. Kordela, Zasady prawa. Studium teoretyczno prawne, Poznań 2012; S. Tkacz, O zintegrowanej koncepcji zasad prawa w polskim prawoznawstwie (Od dogmatyki do teorii), Torun 2013. Najczęściej powoływane prace z literatury zagranicznej: R. Dworkin, Taking Rights Seriously, Cambridge 1977; idem, The Philosophy of Law (Oxford Readings in Philosophy), New York 1977; idem, A Matter of Principle, Cambridge 1985; idem, Law's Empire, Cambridge 1986 oraz R. Alexy, Theorie der Grundrechte, Frankfurt a.M. 1994 (wyd. I 1986).

28 Patrz na przykład konstrukcje M. Kordeli w dziele powołanym w przypisie poprzedzającym. Eadem, Zasady prawa jako normatywna postać wartości, „Ruch Prawniczy, Ekonomiczny i Socjologiczny" 1, 2006; eadem, Możliwość konstruowania ogólnej teorii zasad prawa. Uwagi do koncepcji Roberta Alexy'ego, „Ruch Prawniczy, Ekonomiczny i Socjologiczny” 2, 2007.

29 Z. Ziembiński, Problemy podstawowe..., s. 225 n. Autor ten posługuje się jednak pojęciem niespójności systemu i w inny sposób; na określenie występujących w danym systemie trudności, co do zdefiniowania podstawowych jego założeń i dokonania rozstrzygnięć, co do obowiązywania w systemie którejś z norm ze sobą niezgodnych. W takim ujęciu systemem niespójnym byłby taki, w którym istnieje nadmierna, w stosunku do konieczności wynikającej z marginesu błędu w każdej działalności człowieka, liczba wątpliwości i ocen konkurujących ze sobą bez należytego uporządkowania ich relacjami preferencji. W takim ujęciu Z. Ziembiński posłużył się omawianym pojęciem w pracy „O stanowieniu i obowiązywaniu prawa”, Warszawa 1995, s. 7.

30 Celowi eliminacji tego typu niezgodności służą reguły kolizyjne. Na ten temat na przykład $\mathrm{K}$. Ziemski, Rola i miejsce regut kolizyjnych w procesie dekodowania tekstu prawnego, „Ruch Prawniczy, Ekonomiczny i Socjologiczny" 2, 1978.

31 L. Nowak, Interpretacja prawnicza. Studium z metodologii prawoznawstwa, Warszawa 1973, s. 58 n. Na użytek stosowania dyrektyw kolizyjnych rozważania autora wymagają jednak w tym miejscu tej konkretyzacji — nierealizowalność czy niewykonalność logiczną względnie empiryczną należałoby odnieść nie do jednej normy, a do co najmniej dwóch niezgodnych ze sobą. W tym stanie rzeczy powstawałaby swoista niemożliwość prawna, która, gdyby rzeczywiście była nieusuwalna, prowadziłaby do pozbawienia rozpatrywanego systemu znamion prawności. Należy przy tym podkreślić, że powyższa uwaga dotyczy również tak zwanych niezgodności empirycznych. Oczywiście, o ile owe niezgodności są rzeczywiste i istotne. System zawierający tego typu normy, aczkolwiek być może faktycznie realizowalne (typu: „Otwórz okno, jeśli jest zamknięte” i „Zamknij okno, jeśli jest otwarte") nie prowadzi bowiem do realizacji jakichkolwiek celów, chyba że celem tym byłoby zamęczenie czy ukaranie (przy sprzężeniu tego typu norm z normami sankcjonującymi) adresata. 
przynależenia doń jedynie norm obowiązujących w określonym momencie historycznym ${ }^{32}$.

O niezgodnościach między normami mówi się, biorąc pod uwagę związki logiczne albo związki instrumentalne zachodzące między nimi. Całkowita sprzeczność formalna (logiczna) między normami występuje wtedy, gdy przy tożsamości adresatów (zamienności albo podrzędności zbiorów adresatów tych norm), w sytuacji gdy jedna norma znajduje zastosowanie, znajduje zastosowanie i druga, ale czyn zakazany przez jedną z tych norm jest nakazany przez drugą. O całkowitym wykluczaniu logicznym mówi się odpowiednio jak przy całkowitej sprzeczności logicznej między normami, z tą jednak różnicą, że warunkiem koniecznym realizowania którejś z rozpatrywanych norm jest przekroczenie drugiej z nich. O częściowej niezgodności logicznej między normami (sprzeczności względnie wykluczaniu się) mówi się zaś, gdy nie mamy do czynienia z zamiennością zbiorów: adresatów, okoliczności, w których dana norma znajduje zastosowanie, oraz czynów będących przedmiotem obowiązku adresatów ze względu na dane normy, a ze stosunkiem krzyżowania się zbioru adresatów lub okoliczności, w których dana norma znajduje zastosowanie oraz stosunkiem zamienności czynów będących przedmiotem obowiązku dla adresatów tych norm, z tym iż, gdy określone elementy zbioru wyznaczonego przez pierwszą normę są przedmiotem naka$\mathrm{zu}$, to odpowiadające im elementy zbioru wyznaczonego przez drugą normę są przedmiotem zakazu i odwrotnie (w przypadku częściowej sprzeczności logicznej rozpatrywanych norm) albo realizowanie czynu nakazywanego przez pierwszą z norm uniemożliwia realizację czynu nakazywanego przez drugą z norm (w przypadku częściowego wykluczania się logicznego norm).

Odpowiednio, wyróżnia się pojęcia niezgodności prakseologicznej (instrumentalnej, empirycznej) norm. W tym jednak przypadku jest to odwołane do wiedzy empirycznej, z której wynika, że realizacja jednej normy niweczy skutki realizacji drugiej, całkowicie albo w jakiejś istotnej części ${ }^{33}$.

Treść norm prawnych, jak można stwierdzić, jest wyznaczana nie tylko przez przepisy prawne, ale również przez stosowane dyrektywy interpretacyjne, inferencyjne oraz kolizyjne, które same mogą pozostawać do siebie w różnych relacjach traktowanych w kategoriach zgodności i w znacznej mierze zależą od panują-

32 Powyższych zdań nie należy jednak rozumieć w ten sposób, że dyskwalifikacji jako system prawny podlegałby system norm postępowania w przypadku powstania wątpliwości co do przynależenia doń norm do siebie niezgodnych. Powstanie wątpliwości, wszak to nie to samo co uznanie za obowiązujące w systemie norm względem siebie niezgodnych. W ujęciu Z. Ziembińskiego wątpliwości takie zostają rozstrzygnięte już w oparciu o przyjmowaną koncepcję źródeł prawa, poprzez zastosowanie reguł kolizyjnych. Z. Ziembiński, Problemy podstawowe..., s. 304 n.

33 Z. Ziembiński, O rodzajach niezgodności norm, „Studia Filozoficzne” 2, 1972, s. 88; idem, Problemy podstawowe..., s. 225 n.; idem, Logika..., s. 241; L. Nowak, Interpretacja prawnicza..., s. $76 \mathrm{n}$. 
cych w danym zakresie poglądów na nader różnorakie sprawy ${ }^{34}$. I bynajmniej nie muszą to być zagadnienia o jakimkolwiek zabarwieniu ocennym, aczkolwiek zapewne w przypadku zmian aksjologicznych systemu zmiany są najbardziej dynamiczne i - jeśli tak można rzec — naoczne. Stosunek prawa do wartości najczęściej wyrażają tak zwane zasady prawa, szczególnie o dłuższym rodowodzie albo próbujące wywołać wrażenie takiego rodowodu ${ }^{35}$, bardzo często ujmowane, być może właśnie z tych racji, w postać paremii wyrażanych w łacinie. Większość z tych paremii to wytwór wielowiekowej tradycji i kultury prawniczej, część sięga często jeszcze czasów prawa rzymskiego ${ }^{36}$. Nie sposób jednak nie zauważyć, co szczególnie istotne dla praktyki stosowania prawa, że same te paremie również są przedmiotem interpretacji.

Warto zatem podkreślić, że, mówiąc o spójności systemu prawa, najczęściej dyskutuje się nie pewną własność prawa, a sposoby jej zapewnienia. Właśnie z tego względu, aby nie dochodziło w praktyce jego stosowania do sytuacji, gdy brakowałoby podstaw do jednoznacznego rozstrzygnięcia, jakie są obowiązki prawne podmiotów prawa (krótko: jaka jest ich sytuacja prawna).

\section{VII}

Konkluzja tego tekstu jest dość oczywista. To nie systemowe ujmowanie prawa przeżywa kryzys, ale zmienia się współczesny system prawa, z czym nie radzą sobie niektóre koncepcje teoretycznoprawne. W szczególności komplikuje się katalog źródeł prawa oraz obraz relacji prawa do innych (sub)systemów instytucjonalnych. Nadal jednak można, a dla potrzeb stosowania prawa jest to nawet konieczne, mówić o systemie prawnym jako pewnym konstrukcie myślowym zachowującym spójność teoretyczną, pojęciową i dostatecznie efektywnym społecznie, ekskluzywnie wyznaczającym obowiązki prawne podmiotom prawa.

34 Dla uzmysłowienia sobie, na czym może polegać problem, wystarczy uprzytomnić sobie konsekwencje zmian poglądów na występujące w rzeczywistości związki przyczynowe dla przekształceń w zbiorze norm wyinferowanych na podstawie dyrektyw nakazu czy zakazu przy przyjęciu tak zwanych związków wynikania instrumentalnego.

35 Na przykład na gruncie polskiej nauki prawa zasady clara non sunt interpretanda (aczkolwiek tę paremię można traktować, w pewnej interpretacji, jako polską wersję paremii interpretatio cessat in claris czy in claris non fit interpretatio) czy omnia sunt interpretanda, podczas gdy pierwsza $\mathrm{z}$ nich pochodzi z początku XX wieku, druga zaś została sformułowana na w swojej łacińskiej formie na początku XXI wieku.

${ }^{36}$ E. Waśkowski, Teoria wykładni prawa cywilnego, Warszawa 1936, s. 2; Ch. Perelman, Logika prawnicza. Nowa retoryka, Warszawa 1984, s. 127. Patrz również: Regulae Iuris. Łacińskie inskrypcje na kolumnach Sądu Najwyższego Rzeczypospolitej Polskiej, red. W. Wołodkiewicz, Monachium 2010. 


\section{THE LEGAL SYSTEM IN PERSPECTIVE OF ITS APPLICATION}

\section{Summary}

This study is dedicated to the issue of the system of law in the process of application of law. Taking into consideration the modest (on the assumption) size of the text, only the selected issues directly connected with the problems in question - were discussed within the text. In particular, the issue of the features (characteristics) of the system conditioning its efficiency, namely completeness and consistency. Moreover, the issue of the horizontal fragmentation of the system of law treated as a set in the collective sense and exploration of the elements of the system of law treated as one of the sets in the distributive sense. This, consequently, is analysed within the context of adjudicating on determination of specific legal situations of the legal entities. 